\title{
Assessment of a probiotic Containing Bacillus Subtilis on the Performance and Gut Health of Laying Japanese Quails (Coturnix Coturnix Japonica)

\section{-Author(s)}

\section{Manafi $\mathrm{M}^{\prime}$}

Khalaji $S^{\prime}$

Hedayati M'

Department of Animal Sceicne, Faculty of Agricultural Sciences, Malayer University, Malayer, Iran.

\section{ABSTRACT}

The present study was carried out to determine the effects of the inclusion of a spore-forming probiotic (Bacillus subtilis) in laying Japanese quail diets as an alternative to growth-promoting antibiotics to help produce healthy eggs and meat. This experiment was conducted as a completely randomized design with three treatments (control, $0.05 \%$ bacitracin methylene disalicylate (BMD), or $0.1 \%$ Bacillus subtilis) of five replicates of 11 quails each. Feed intake and egg production were recorded daily on cage basis. Body weight was determined at the beginning and end of the trial ( 36 and 42 weeks). At the end of the experiment (42 weeks), antibodies against Newcastle disease and avian influenza, egg components, Haugh units, eggshell quality and breaking strength, blood parameters, cecal microbial population, villus length, and crypt depth were measured. The dietary inclusion of Bacillus subtilis and BMD significantly $(p \leq 0.05)$ increased egg production and egg weight; however, eggshell thickness and breaking strength, Haugh units, and eggshell percentages were not affected. The dietary addition of both products significantly $(p \leq 0.05)$ decreased plasma cholesterol levels and increased LDL levels, as well as antibody levels against Newcastle disease and avian influenza $(p \leq 0.01)$. In birds fed Bacillus subtilis and BMD, crypt depth was reduced, but villus height and villus to crypt ratio were significantly increased $(p \leq 0.001)$ compared with those fed the basal diet. Cecal coliforms, E. coli, and Salmonella counts were reduced $(p \leq 0.01)$ in quails fed the diets containing Bacillus subtilis and BMD compared those quails fed the non-supplemented diet. The results of this study demonstrated that in absence of AGPs, the inclusion of a spore-forming probiotic partially improves the performance of laying quails.

\section{INTRODUCTION}

Quail production is one of the fastest growing sectors in poultry industry across the globe. In addition to their excellent flavor, quail eggs have 3-4 times higher nutritional value than that of free-range chicken eggs. Quail eggs contains $13 \%$ protein and $140 \mu \mathrm{g}$ of vitamin B1 (Tavaniello et al., 2014). They are much richer in vitamin B2, choline, iron, potassium, calcium and phosphorus than chicken eggs and contain high HDL cholesterol levels, the 'good' cholesterol, and therefore, can be consumed by elderly people (Dogan et al., 2013). The health benefits of quail eggs include treatment of anemia, removal of toxins and heavy metals from the blood, strong anti-cancer activity, inhibiting cancer growth, nourishment of the prostate gland, restauration of sexual potency, memory and brain activity enhancement, and strengthening the immune system (Pellegrini et al., 2015). Other advantages of quail production are minimum floor space required for production, low investments, early sexual maturity, and high egg production. 
Probiotics have been described as alternatives to antibiotic growth promoters for poultry against oxidative stress, improving mucosal and general immunity and increase their performances (Gleeson et al., 2012). Stressful situations in poultry farms may increase the incidence of gastrointestinal disease, particularly of diarrhea during production period and are likely to cause increased susceptibility to infections in the upper respiratory tract in part to suppress the immune system leading to growth rate deficiencies (Manafi, 2015). Probiotics can prevent illnesses during the laying period, which is one of the priorities for quail farmers to produce healthy eggs, and also to nutritionists, who are interested in minimizing gastrointestinal disorders (Pellegrini et al., 2015).

It has been demonstrated that consumption of probiotic can enhance the immune system and health (Corthesy et al., 2007). Therefore, probiotics can be used to directly maximize performance of birds by preventing the immunosuppression caused by prolonged stress and the presence of pathogenic bacteria, thus reducing the quail's susceptibility to diseases and the incidence of acute upper respiratory tract infections, diarrheas and their associated symptoms (Guarino et al., 2009).

The use of spore-forming probiotics has several advantages. When the bacterium turn into spores, it forms two layers of protein around it. These layers protect the bacterium from environmental stressors, which allow spore-forming probiotics to be included in diets containing possible aggressive in-feed components such as coccidiostats (Tavaniello et al., 2014). Bacillus spores are relatively inexpensive to produce, steam palatable and highly effective to modify the intestinal microflora to deactivate Salmonella species, E. coli, and Clostridium perfringens. It is believed that Bacillus subtilis C-3102 spores vegetate in the intestinal lumen and consume oxygen, providing a more anaerobic condition, which is favorable to native Lactobacilli spp. They then proliferate and produce lactic acid that controls pathogens and increases the utilization of essential minerals.

A number of studies in growing quails reported that egg production significantly increased in commercial flocks fed alternatives to antibiotic growth promoters, which have been increasingly banned worldwide (Tavaniello et al., 2014). The objective of the present study was to compare the effects of the dietary inclusion of a commercial spore-forming probiotic on performance and egg quality parameters of laying Japanese quails with an antibiotic growth promoter.

\section{MATERIALS AND METHODS}

\section{Bird management and experimental design}

The experimental procedures were approved by the bioethical committee of Malayer University according to the procedures for the protection of animals reared for scientific experimental purposes (protocol number: 84/5-1-183). The quails were maintained in cages according to the guidelines of Iranian Council on Animal Care.

Quails were housed in thermostatically-controlled wire battery cages $(152 \times 46 \times 27 \mathrm{~cm})$. A lighting program of $17 \mathrm{~h}$ light and $7 \mathrm{~h}$ dark was adopted during the experimental period.

One hundred and sixty five laying Japanese quails (Coturnix coturnix japonica) with 36 weeks of age were distributed into three treatment groups with five replicates of 11 quails each (8 females and 3 males). Birds were fed a basal diet containing corn-soybean meal (control); the control diet plus $0.05 \%$ bacitracin methylene disalicylate (BMD), or the control diet plus $0.1 \%$ Bacillus subtilis (Calsporin ${ }^{\circledR}$, Calpis Co. Ltd, Japan) from 37 to 42 weeks of age. Calsporin is a preparation of Bacillus subtilis C-3102 (DSM 15544) with a minimum of $1.0 \times 10^{10}$ viable spores per gram. The quail breeder mash diet was manufactured at the experimental facilities. The diet was formulated to supply the birds' nutritional requirements according to the recommendations of the NRC (NRC, 1994). The ingredients and chemical composition of the coccidio stat-free basal diet is shown in Table 1. The Bacillus subtilis and bacitracin methylene disalicylate were obtained from local market in powder form and added on top to the basal diet.

The tested products were fed to the quails three weeks before starting the experiment, which was considered as adaptation period. Feed and water were supplied ad libitum.

\section{Performance parameters}

Egg production was recorded daily per cage unit during the adaptation period, and the average egg production rate (hen-day percent) was calculated. Feed intake was calculated as feed offer minus feed residues in the feeder, and reported as gram per bird per day. Feed conversion ratio (FCR) was calculated as grams of feed per grams of egg produced. Weekly egg production was weighed to determine egg weight. Egg mass was then calculated as egg weight $\times$ number of eggs produced. 
Table 1 - Composition of the basal diet of layer Japanese quail on as-fed basis (36-42 weeks of age)

\begin{tabular}{lc}
\hline Feed ingredients (\%) & \\
\hline Corn & 65.3 \\
Soybean meal & 19 \\
\hline Eggshell powder & 7.2 \\
Corn gluten & 5.00 \\
Dicalcium phosphate & 1.40 \\
\hline Soybean oil & 1 \\
DL-Methionine & 0.31 \\
L-Lysine & 0.09 \\
\hline Mineral mixture1 & 0.25 \\
Vitamin mixture ${ }^{2}$ & 0.25 \\
Salt & 0.20 \\
\hline Analyzed chemical composition & 2950 \\
\hline Metabolizable energy (kcal/kg) & 18 \\
\hline Total protein (\%) & 3.10 \\
Total calcium (\%) & 0.45 \\
\hline Available phosphorous (\%) & 0.85 \\
Lysine (\%) & 0.52 \\
Methionine (\%) & 0.82 \\
Methionine + Cysteine (\%) & 0.18 \\
\hline Sodium (\%) & \\
\hline
\end{tabular}

'Mineral mixture provided $500 \mathrm{mg}$ of $\mathrm{FeSO}_{4^{\prime}} 65 \mathrm{mg}$ of $\mathrm{CuSO}_{4^{\prime}} 100 \mathrm{mg}^{\prime}$ of $\mathrm{MnSO}_{4^{\prime}}, 0.5 \mathrm{mg}$ of lodine and $0.22 \mathrm{gm}$ of Selenium per $\mathrm{kg}$ of feed.

${ }^{2}$ Vitamin mixture provided $11000 \mathrm{IU}$ of vitamin A, $1800 \mathrm{IU}$ of vitamin D3,11 mg of vitamin E, 2 mg of vitamin $\mathrm{K} 3,4 \mathrm{mg}$ of vitamin B1, $5.7 \mathrm{mg}$ of vitamin B2, 2 mg of vitamin B6, $0.5 \mathrm{mg}$ of folic acid, $2500 \mathrm{mg}$ of choline chloride, $0.125 \mathrm{mg}$ of antioxidants, 0.03 $\mathrm{mg}$ of Biotin and $0.024 \mathrm{mg}$ of vitamin B12 per $\mathrm{kg}$ of feed.

\section{Egg quality parameters}

Egg components, Haugh unit, eggshell thickness, and eggshell breaking strength were measured at the end of the experimental period (42 weeks of age). Eggshell breaking strength was measured in two eggs per replicate chosen at random using an eggshell force gauge (model-II, Robotmation Co. Ltd., Tokyo, Japan). Eggshell thickness was measured using an ultrasonic thickness gauge (Echometer 1062, Robotmation Co. Ltd.). Haugh unit was determined in an egg multi-tester equipment (EMT-5200, Robotmation Co. Ltd.). Eggs were broken, the internal contents were removed, and eggshells were dried at room temperature for $48 \mathrm{~h}$ to determine eggshell weight, by a digital balance $(0.001$ g accuracy).

\section{Serum biochemistry and immune response parameters}

Two quails per cage (one male and one female) were randomly selected from all groups, and individual blood samples were collected in non-heparinized tubes at the end of the experimental period (42 weeks of age). The serum was separated and stored at $-20^{\circ} \mathrm{C}$ until further analyses. Each serum sample was analyzed for glucose, cholesterol, low-density lipoprotein (LDL), high-density lipoprotein (HDL), and triglyceride levels, and for alanine transaminase (ALT), gamma glutamyl transferase (GGT), alkaline phosphatase (ALP) enzyme activities. Antibody titers against Newcastle disease (ND) and avian Influenza (Al) were measured by commercial ELISA kits (Boehringer Mannheim Hitachi 704 automatic analyzer, Japan).

\section{Intestinal morphology parameters}

At the end of the experiment, four birds per treatment were randomly selected, stunned, and killed for the evaluation of ileal morphology. The digestive tract with its contents was aseptically removed, and the ileum was detached from the Meckel's diverticulum up to $1 \mathrm{~cm}$ proximal to the ileocecal junction and later dried on desiccant paper. A 2-cm section of ileum was removed from the middle part of the ileum and gently flushed using PBS (pH 7.2).

Tissue sections were immediately fixed in 10\% neutral buffered formalin, which was changed three times to complete fixation. A single $0.5 \mathrm{~cm}$ sample was cut from each ileal section, dehydrated with increasing ethanol concentrations (70, 80, 95, and 100\%), cleared in xylene, and placed into polyfin embedding wax. Tissue sections $(2 \mu \mathrm{m})$ were cut using a microtome (Leitz-1512 Microtome, Leitz, Wetzlar, Germany), floated onto slides, and stained with hematoxylin (Gill no. 2, Sigma, St. Louis, MO) and eosin (H\&E) (Sigma).

Villus height and crypt depth images were taken using a digital camera under light microscopy. In total, 12 images from four sections of each ileal section were taken to measure 24 villus heights and crypt depths by imaging software. Villus length was measured from the tip of the villus to the valley, and crypt depth measured from the valley to the basolateral membrane. Intestinal morphology measurements were analyzed by the GLM procedure of SAS software (2007).

\section{Enumeration of cecal bacterial population}

At the end of the experiment, two quails per cage were bled by the jugular vein for the extraction of cecal contents, which were pooled for serial dilution. Microbial populations were determined by serial dilution $\left(10^{-4}\right.$ to $\left.10^{-6}\right)$ of cecal samples in anaerobic diluents before inoculation onto Petri dishes with sterile agar, as described by Bryant \& Burkey (1953).

Nine sterile lidded test tubes containing $9 \mathrm{~mL}$ phosphate buffer solution as diluent were prepared and approximately $1 \mathrm{~g}$ of the cecal contents taken by sterile swab and homogenized for 3 min before being submitted to the microbiology lab under refrigeration 
(Bryant \& Burkey, 1953) and mixed, employing aseptic techniques. For serial dilution of the cecal contents, $1 \mathrm{~mL}$ out of the $10 \mathrm{~mL}$ buffer plus cecal content solution was removed using a $1000 \mu \mathrm{L}$ sampler, transferred to tube No. 1, and thoroughly mixed. This procedure was repeated until a 1:9 dilution (tube No. 9) was achieved. A volume of $1.0 \mathrm{~mL}$ of each test tube was transferred to Petri dishes with the selective media. E. coli was grown on eosin methylene blue agar, Salmonella on Salmonella Shigella agar (Merck, Germany), and coliforms on McConkey agar (Darmstadt, Germany). Petri dishes were then aerobically incubated at $37^{\circ} \mathrm{C}$ for $24 \mathrm{~h}$. Colonies were manually counted between 24 and $48 \mathrm{~h}$ after inoculation, adjusted to $\times 10^{9}$, and reported as colony forming units (cfu), defined as distinct colonies measuring at least $1 \mathrm{~mm}$ in diameter.

\section{Statistical Analysis}

Data were analyzed according to a completely randomized experimental design. The GLM procedure of SAS (SAS Institute, 2007) was applied for parameters measured only once during the experimental period, and the MIXED procedure of SAS (SAS Institute, 2007) for those repeatedly measured during the experimental period. Age was considered the main factor and initial values considered as a covariate effect in the model. Differences between treatment means were tested using Duncan's multiple comparison tests for main effects and Tukey's test for interactions. Statistical significance was declared at $\mathrm{p} \leq 0.05$.

\section{RESULTS}

The 2-week pre-experimental addition of probiotic to laying quail diets showed had no influence ( $p>0.05$ ) on egg production or egg weight. The dietary inclusion of Bacillus subtilis and bacitracin significantly increased egg production compared with the control group (Table 2). Feed conversion ratio (FCR; $g$ feed/g eggs

Table 2 - Effect of the dietary addition of Bacillus subtilis on the performance of laying Japanese quails.

\begin{tabular}{lccc}
\hline Treatment & $\begin{array}{c}\text { Egg production } \\
\text { (hen-day \%) }\end{array}$ & $\begin{array}{c}\text { FCR } \\
\text { (g feed/g egg } \\
\text { produced) }\end{array}$ & $\begin{array}{c}\text { Feed intake } \\
\text { (g/quail/day) }\end{array}$ \\
\hline Control & $69.09^{c}$ & $3.57^{\mathrm{a}}$ & 203.15 \\
Bacitracin & $72.74^{\mathrm{a}}$ & $3.28^{\mathrm{c}}$ & 205.83 \\
Bacillus subtilis & $72.22^{\mathrm{b}}$ & $3.42^{\mathrm{b}}$ & 204.35 \\
SEM & 0.13 & 0.04 & 1.03 \\
P-Value & 0.001 & 0.001 & 0.54 \\
\hline
\end{tabular}

a-cMeans with different letters within the same column are significantly different $(p \leq 0.05) ; F C R$ : Feed conversion ratio; Bacitracin (bacitracin methylene disalicylate): antibiotic growth promoter; SEM = pooled standard error of column wise means comparison. produced) was significantly $(p \leq 0.05)$ reduced in the bacitracin and Bacillus subtilis groups compared with the control group. Feed intake was not affected by dietary treatments (Table 2). The egg weight in both feed-additive groups was significantly $(p \leq 0.05)$ higher than that of the control group.

Eggshell thickness, eggshell breaking strength, Haugh units, and eggshell percentage, however, were not affected by addition of Bacillus subtilis or bacitracin (Table 3).

The effects of Bacillus subtilis and bacitracin on plasma parameters and antibody responses of quails are shown in Table 4. The addition of both feed additives significantly $(p \leq 0.05)$ reduced plasma cholesterol and LDL levels during the experimental period, but had no effect on HDL levels. The dietary inclusion of Bacillus subtilis and bacitracin significantly $(p \leq 0.01)$ improved the antibody response against Newcastle disease and avian influenza. Plasma total protein, calcium, phosphorus, glucose, and the activities of serum alanine transaminase, alkaline phosphatase and aspartate transaminase were not affected by the dietary addition either Bacillus subtilis or bacitracin.

The effects of Bacillus subtilis and bacitracin on ileal morphology of laying Japanese quails are shown in Table 5. In birds fed Bacillus subtilis and bacitracin, crypt depth was reduced, and villus height and villus to crypt ratio were significantly increased $(p \leq 0.001)$ compared with the group fed basal diet. The number of goblet cells was significantly $(p \leq 0.01)$ reduced by the inclusion of both these feed additives in comparison with the control group.

There was a significant $(p \leq 0.01)$ reduction in cecal coliforms, E. coli, and Salmonella populations of Japanese quails fed diets containing Bacillus subtilis and bacitracin when compared with those fed the basal diet.

\section{DISCUSSION}

When administered in adequate amounts, probiotics, as live microorganisms, have beneficial effects on the performance and health status of the host. Studies have confirmed that selected heat-resistant spore-forming Bacillus species fed as probiotics can markedly reduce Salmonella and Clostridium populations, proving to be cost-effective feed additives in commercial poultry production (Tellez et al., 2006). In the current study, the dietary addition of Bacillus subtilis increased the egg production and egg weight of Japanese quails. The absence of feed intake differences among the different 
Table 3 - Effect of the dietary addition of Bacillus subtilis on egg weight and egg quality of laying Japanese quails.

\begin{tabular}{lccccc}
\hline Treatment & Egg weight $(\mathrm{g})$ & Eggshell thickness $(\mathrm{mm})$ & Eggshell breaking strength $(\mathrm{kg})$ & Haugh units & Eggshell $(\%)$ \\
\hline Control & $11.15^{c}$ & 2.17 & 0.22 & 91.24 & 8.29 \\
Bacitracin & $11.23^{\mathrm{b}}$ & 2.19 & 0.21 & 90.44 & 8.69 \\
Bacillus subtilis & $11.26^{\mathrm{a}}$ & 2.21 & 0.21 & 87.47 & 8.69 \\
SEM & 0.01 & 0.03 & 0.01 & 2.39 & 0.32 \\
P-Value & 0.001 & 0.69 & 0.88 & 0.49 & 0.65 \\
\hline
\end{tabular}

a-cMeans with different letters within the same column are significantly different ( $\mathrm{p} \leq 0.05)$; Bacitracin (bacitracin methylene disalicylate): antibiotic growth promoter; $S E M=$ pooled standard error of column wise means comparison.

Table 4 - Effect of the dietary addition of Bacillus subtilis on the blood parameters and antibody response of laying Japanese quails.

\begin{tabular}{lcccccccccccccc}
\hline Treatment & $\begin{array}{c}\text { Cholesterol } \\
\mathrm{mg} / \mathrm{dL}\end{array}$ & $\begin{array}{c}\text { Triglyceride } \\
\mathrm{mg} / \mathrm{dL}\end{array}$ & $\begin{array}{c}\mathrm{HDL} \\
\mathrm{mg} / \mathrm{dL}\end{array}$ & $\begin{array}{c}\mathrm{LDL} \\
\mathrm{mg} / \mathrm{dL}\end{array}$ & $\begin{array}{c}\mathrm{AST} \\
\mathrm{mg} / \mathrm{dL}\end{array}$ & $\begin{array}{c}\mathrm{ALT} \\
\%\end{array}$ & $\begin{array}{c}\text { ALP } \\
10^{6} / \mu \mathrm{ll}\end{array}$ & $\begin{array}{c}\text { WBC } \\
10^{3} / \mu \mathrm{ll}\end{array}$ & $\begin{array}{c}\mathrm{Glucose} \\
\mathrm{mg} / \mathrm{dL}\end{array}$ & $\begin{array}{c}\text { Protein } \\
\mathrm{g} / \mathrm{dL}\end{array}$ & $\begin{array}{c}\text { Plasma } \\
\text { Calcium } \\
\mathrm{mg} / \mathrm{dL}\end{array}$ & $\begin{array}{c}\text { Plasma } \\
\text { phosphorus } \\
\mathrm{mg} / \mathrm{dL}\end{array}$ & $\begin{array}{c}\text { Al } \\
\mathrm{ND}\end{array}$ \\
\hline Control & $330.40^{\mathrm{a}}$ & 579 & 89.2 & $122.8^{\mathrm{ab}}$ & 290.2 & 2 & 5192 & 15240 & 300 & 4.58 & 19.18 & 6.04 & $7.2^{\mathrm{a}}$ & $7^{\mathrm{a}}$ \\
Bacitracin & $285.80^{\mathrm{ab}}$ & 607 & 93 & $135.8^{\mathrm{a}}$ & 294.2 & 2.4 & 2516 & 1522 & 314 & 4.44 & 15.76 & 6.04 & $5.4^{\mathrm{b}}$ & $6.4^{\mathrm{a}}$ \\
Bacillus subtilis & $207.00^{\mathrm{b}}$ & 412 & 90.2 & $85^{\mathrm{b}}$ & 287.6 & 2 & 43425 & 14560 & 292 & 4.48 & 15.34 & 4.7 & $4.8^{\mathrm{b}}$ & $4^{\mathrm{b}}$ \\
SEM & 29.57 & 89.33 & 10.09 & 13.8 & 23.7 & 0.29 & 935 & 660 & 0.24 & 0.27 & 1.55 & 0.83 & 0.49 & 0.34 \\
P-Value & 0.03 & 0.28 & 0.96 & 0.05 & 0.98 & 0.55 & 0.16 & 0.71 & 0.81 & 0.93 & 0.19 & 0.41 & 0.01 & 0.001 \\
\hline
\end{tabular}

a-bMeans with different letters within the same column are significantly different (p $\leq 0.05)$; HDL: High-density lipoprotein; LDL: Low-density lipoprotein; AST: aspartate aminotransferase; ALT: Alanine Aminotransferase, ALP: Alkaline phosphatase; WBC: white blood cell;ND: Newcastle disease antibody titers, Al: Avian influenza antibody titers. Bacitracin (bacitracin methylene disalicylate): antibiotic growth promoter; SEM = pooled standard error of column wise means comparison.

Table 5 - Influence of Bacillus subtilis addition of diets on cecal microbial populations and ileum morphological characteristics, including villus height, crypt depth, and the villus:crypt ratio of quails .

\begin{tabular}{|c|c|c|c|c|c|c|c|}
\hline Treatment & Villus height $(\mu \mathrm{m})$ & Crypt depth $(\mu \mathrm{m})$ & Villus:crypt ratio & $\begin{array}{l}\text { Number of } \\
\text { goblet cellst }\end{array}$ & $\begin{array}{c}\text { Coliforms } \\
\left(\log _{18 \mathrm{cfu} / \mathrm{g}} \text { of }\right. \\
\text { DM) }\end{array}$ & $\begin{array}{c}\text { Salmonella } \\
\left(\log _{10} \mathrm{cfu} / \mathrm{g} \text { of }\right. \\
\text { DM) }\end{array}$ & $\begin{array}{c}\text { E. coli } \\
\left(\log _{1 \mathrm{c}} \mathrm{cfu} / \mathrm{g} \text { of }\right. \\
\text { DM) }\end{array}$ \\
\hline Control & $469^{b}$ & $91^{a}$ & $5.15^{c}$ & $10.47^{a}$ & $3.33^{a}$ & $6.7^{a}$ & $3.25^{a}$ \\
\hline Bacitracin & $660^{a}$ & $77^{b}$ & $8.53^{\mathrm{a}}$ & $8.27^{b}$ & $2.38^{b}$ & $5.21^{b}$ & $2.19^{b}$ \\
\hline Bacillus subtilis & $649^{a}$ & $80^{b}$ & $8.13^{b}$ & $8.15^{b}$ & $2.32^{b}$ & $4.42^{c}$ & $2.14^{\mathrm{b}}$ \\
\hline SEM & 0.06 & 0.01 & 0.12 & 0.09 & 0.06 & 0.16 & 0.04 \\
\hline P-Value & 0.001 & 0.001 & 0.001 & 0.001 & 0.001 & 0.001 & 0.001 \\
\hline
\end{tabular}

a-cMeans with different letters within the same column are significantly different ( $\leq \leq 0.05)$; Bacitracin (bacitracin methylene disalicylate): antibiotic growth promoter; SEM = pooled standard error of column wise means comparison.

t number of goblet cells per mm of villus length.

treatments demonstrated that all groups consumed similar amounts of feed to produce eggs. Therefore, the differences in egg production among different treatments may only attributed to the effect of the inclusion of the evaluated feed additives. These findings are consistent, in general, with those of Abdel-Azeem (2005), Grimes et al. (2008), and Vilà et al. (2009), who reported the improvement of performance indexes of laying hens, turkey poults, and broilers fed probiotics. The enhancement of laying Japanese quail performance observed in the present study may be attributed to a reduction in the proliferation of pathogenic bacteria due to gut environmental changes, as a result of better intestinal microbial balance, nutrient utilization, and enzymatic activities in the birds' gastrointestinal tract (Corzo et al., 2009). Moreover, Bacillus subtilis spores are effective and economical exclusion agents, enhancing the digestion and absorption of consumed feed, and consequently, improving body weight and feed conversion ratio (La Ragione and Woodward, 2003). Probiotic supplementation to laying Japanese quail diets significantly increased egg production and egg weight (Ayasan et al., 2006). Other studies, however, did not report any beneficial effects of dietary probiotic supplementation on the egg production of laying Japanese quails (Onol et al., 2003) or laying hens (Yoruk et al., 2004). In the current study, and in agreement with the of Nahashon et al. (1996) and Tortuero \& Fernandez (1995) in layers, the dietary inclusion of a probiotic containing Bacillus subtilis significantly increased the egg weight of Japanese quails. On the other hand, no effects of such probiotics were found by Haddadin et al. (1996) and Chen et al. (2009) in layers and Balevi et al. (2001) and Yoruk et al. (2004) in Japanese quails. These controversial results might be related to probiotic strain, concentration, and 
the form of bacteria used during the preparation of probiotic (viability, dryness or their products). Different studies (Nahashon et al., 1992; Tortuero \& Fernandez, 1995; Nahashon et al., 1996; Haddadin et al., 1996) comparing diets containing higher bacterial counts. Thus, egg weight increase may be related to the vital form of probiotic bacteria at higher doses, of up to $\log _{10} \mathrm{cfu} / \mathrm{g}$ of probiotic product.

The addition of Bacillus subtilis had no effect on eggshell percentage, thickness, or breaking strength. However, Ayasan et al. (2006) obtained higher eggshell weight when supplementing a probiotic in laying Japanese quail diets. A similar result was found in layers fed aprobiotic-supplemented diet (Pedroso et al., 2001; Onol et al., 2003; Yoruk et al., 2004). Mahdavi et al. (2005), on the other hand, reported that addition of a probiotic had no significant effect on eggshell hardness, eggshell thickness, or Haugh unit scores. A significant improvement of internal egg quality, as measured in Haugh units, was reported in layers fed a probiotic containing dried distillers grain and corn with solubles (Jensen \& Maurice, 1978). Subsequent studies indicated that trace elements may be involved in the mineralization of eggshells (Jensen et al., 1978). Tortuero \& Fernandez (1995) reported that variations in plasma mineral levels of laying hens fed selected microbial cultures as probiotic supports the hypothesis that trace elements improve albumen quality with microbial supplementation (Tortuero \& Fernandez, 1995).

In the present study, dietary probiotic inclusion significantly reduced plasma cholesterol levels relative to the control treatment, and LDL levels relative to the antibiotic treatment. These findings are in general agreement with previous studies (Haddadin et al., 1996; Mahdavi et al., 2005) that demonstrated the role of gastrointestinal tract microorganisms in the recycling of lipids. In Japanese quails, Genedy \& Zewil (2003) reported a decline in total lipid and cholesterol blood levels of the birds fed a probiotic. In the presence of specific microorganisms such as Bacillus subtilis, the reabsorption of primary bile salts is prevented, which then can be converted into secondary bile salts. Moreover, such microorganisms are able to synthesize esterase and lipase enzymes, converting free fatty acids (except triglycerides) into their esterified forms in the intestine, reducing the chance of triglyceride absorption into the plasma (Pellegrini et al., 2015). The mechanism of the cholesterol-lowering effects of probiotics is the enzymatic deconjugation of bile acids by the hydrolysis of bile salts which allows them to bind to cholesterol in the small intestine (Begley et al., 2006).
Bacillus subtilis significantly reduced crypt depth and increased villus height and villus to crypt ratio in the ileum. An increase in villus length in broilers fed probiotics and prebiotics was reported, which was associated with an increased presence of lactobacilli and bifidobacterial, and with reduced intestinal colonization by Salmonella and coliforms (Baurhoo et al., 2007). Feeding Bacillus subtilis in current study markedly reduced the populations of Salmonella, coliforms and E. coli.

The rationale of the direct administration of probiotic bacteria to broilers is to reduce infections caused by pathogens by the mechanism of competitive exclusion, in which bacteria compete for space and nutrients. Hence, the early administration of 'good' bacteria for competitive exclusion has been proposed as a method to prevent undesirable infections. There are several reports on the capacity of live bacterial cultures (Callaway et al., 2008; Corrier et al., 1998; Nisbet et al., 1998; Wagner et al., 2003) and probiotic organisms (Higgins et al., 2007; Higgins et al., 2008; Higgins et al., 2010; Patterson \& Burkholder, 2003; Vicente et al., 2008) to reduce the colonization of the gastrointestinal tract of poultry by opportunistic pathogens. The current study showed that the dietary inclusion of Bacillus subtilis enhanced the birds' immunity against Newcastle disease and avian influenza. The destruction of the bursa of Fabricius by viral agents impairs the humoral immune response of poultry. Most of probiotics benefit the host by immune regulation, particularly through the balanced control of pro-inflammatory and anti-inflammatory cytokines (Li et al., 2009; Foligne et al., 2010; Jobin, 2010). Several studies have provided unequivocal evidence that certain probiotics strains are able to stimulate several aspects of innate (Farnell et al., 2006; Boirivant et al., 2008; Romanin et al., 2010; Weiss et al., 2010) and humoral immunity (Galdeano et al., 2009). Moreover, the extracellular enzymes produced by Bacillus subtilis may boost the general gut immune function (Chen et al., 2009). Yet, further knowledge on how probiotics mediate these health benefits, specifically relative to the prevention of Salmonella infections, is required.

In conclusion, laying Japanese quails fed a probiotic containing Bacillus subtilis significantly increase egg production, egg weight, and villus height values, and reduced plasma cholesterol and LDL levels, as well as the intestinal populations of Salmonella, coliforms, and E. coli compared with the control group. The sporeforming probiotic partially enhanced the performance parameters, promoted significant changes in gut 
physiology, and improved the general health of the laying Japanese quails in the current study. Considering the recent international legislation and domestic consumer pressures to withdraw antibiotics, sporeforming probiotics can offer an alternative to such compounds for the production of healthy in Japanese quail eggs.

\section{REFERENCES}

Abdel-Azeem FA, Nematallah GM, Ibrahim Faten AA. Effects of dietary protein level with some natural biological feed additives supplementation on productive and physiological performance of Japanese quails. Egyptian Poultry Science 2005;25(2):497-525.

Ayasan T,Ozcan BD, Baylan M, Canogullari S.The Effects of dietary inclusion of probiotic protexin on egg yield parameters of japanese quails (Coturnix coturnix Japonica). International Journal of Poultry Science 2006;5(8):776-779.

Balevi T, Ucan US, Coskun B, Kurtoglu V, Cetingul S. Effect of dietary probiotic on performance and humoral immune response in layer hens. British Poultry Science 2001;42:456-461

Baurhoo B, Letellier A, Zhao X, Ruiz-Feria CA. Cecal populations of lactobacilli and bifidobacteria and Escherichia coli populations after in vivo Escherichia coli challenge in birds fed diets with purified lignin or mannanoligosaccharides. Poultry Science 2007;86:2509-2516.

Begley M, Hill C, Gahan CGM. Bile salt hydrolase activity in probiotics. Applied and Environmental Microbiology 2006;72:1729-1738.

Boirivant $\mathrm{M}$, Amendola A, Butera A. Intestinal microflora and immunoregulation. Molecular Immunology 2008;1:S47-S49.

Bryant MP, Burkey LA. Cultural methods and some characteristics of some of the more numerous groups of bacteria in the bovine rumen. Journal of Dairy Science 1953;36:205-217.

Callaway TR, Edrington TS, Anderson RC, Harvey RB, Genovese KJ, et al. Probiotics, prebiotics and competitive exclusion for prophylaxis against bacterial disease. Animal Health Research Reviews/Conference of Research Workers in Animal Diseases 2008;9:217-225.

Chen KL, Kho WL, You SH, Yeh RH, Tang SW, Hsieh CW. Effects of Bacillus subtilisvar. natto and Saccharomyces cerevisiae mixed fermented feed on the enhanced growth performance of broilers. Poultry Science 2009;88:309-315.

Corzo A, Loar RE, Kidd MT. Limitations of dietary isoleucine and valine in broiler chick diets. Poultry Science 2009;88(9):1934-1938.

Corrier DE, Nisbet DJ, Byrd JA, Hargis BM, Keith NK, Peterson M, et al. Dosage titration of a characterized competitive exclusion culture to inhibit Salmonella colonization in broiler chickens during growout. Journal of Food Protection 1998;61:796-801.

Corthesy B, Gaskins HR, Mercenier A. Cross-talk between probiotic bacteria and the host immune system. Journal of Nutrition 2007;137:781S-790S.

Dogan N, Tulin A, Emre K, Ali A, Mehmet ZF, Mustafa KU. Japanese quail meat quality:Characteristics, heritabilities, and genetic correlations with some slaughter traits. Poultry Science 2013;92:1735-1744.

Farnell MB, Donoghue AM, Santos FS, Blore PJ, Hargis BM, Tellez G, et al. Upregulation of oxidative burst and degranulation in chicken heterophils stimulated with probiotic bacteria. Poultry Science 2006;85:1900-1906.
Foligne B, Dewulf J, Breton J, Claisse O, Lonvaud-Funel A, Pot B. Probiotic properties of non-conventional lactic acid bacteria: Immunomodulation by Oenococcus oeni. International Journal of Food Microbiology 2010,140:136-145

Galdeano CM, Leblanc M, Carmuega E, Weill R, Perdigon G. Mechanisms involved in the immunostimulation by probiotic fermented milk. Journal of Dairy Research 2009;76:446-454.

Genedy SG, Zewil HS. Evaluation of using medicinal plants as feed additives in growing Japanese quail diets. Proceedings of the 68th Scientific Conference of Polish Animal Production Society; 2003 Sep 9-12; Krakov. Poland; 2003

Gleeson M, Bishop NC, Oliveira M, McCauley T, Tauler P, Lawrence C. Effects of a Lactobacillus salivarius probiotic intervention on infection, cold symptom duration and severity, and mucosal immunity in endurance athletes. International Journal of Nutrition and Metabolism 2012:4:235-242.

Grimes JL, Rahimi S, Oviedo E, Sheldon BW, Santos FBO. Effects of a directfed microbial (Primalac) on turkey poult performance and susceptibility to oral Salmonella challenge. Poultry Science 2008;87:1464-1470.

Guarino A,Lo Vecchio A, Canani RB. Probiotics as prevention and treatment for diarrhea. Gastroenterology 2009;25:18-23.

Haddadin MSY, Abdulrahim SM, Hashlamoun EAR, Robinson RK. The effects of Lactobacillus acidophilus on the production and chemical composition of hen's eggs. Poultry Science 1996;75:491-494.

Higgins JP, Higgins SE, Vicente JL, Wolfenden AD, Tellez G, Hargis BM. Temporal effects of lactic acid bacteria probiotic culture on Salmonella in neonatal broilers. Poultry Science 2007;86:1662-1666.

Higgins SE, Higgins JP, Wolfenden AD, Henderson SN, Torres-Rodriguez A, Tellez G, et al. Evaluation of a Lactobacillus-based probiotic culture for the reduction of Salmonella enteritidis in neonatal broiler chicks. Poultry Science 2008;87:27-31.

Higgins JP, Higgins SE, Wolfenden AD, Henderson SN, Torres-Rodriguez A, Vicente $\mathrm{JL}$, et al. Effect of lactic acid bacteria probiotic culture treatment timing on Salmonellaenteritidis in neonatal broilers. Poultry Science 2010;89:243-247.

Jensen LS, Chang CH, Wilson SP. Interior egg quality: improvement by distillers feeds and trace elements. Poultry Science 1978;57:448-454

Jensen LS, Maurice DV. Effect of chromium and corn fermentation solubles on interior egg quality. Poultry Science 1978;57:1147-1151.

Jobin C. Probiotics and ileitis: could augmentation of TNF/NFkappaB activity be the answer? Gut Microbiology 2010;1:196-199.

Knarreborg A, Brockmann E, Høybye K, Knap I, Lund B, Milora N, et al. Bacillus subtilis (DSM17299) modulates the ileal microbial communities and improves growth performance in broilers. International Journal of Probiotics and Prebiotics 2008;3:83-88.

La Ragione RM, Woodward MJ. Competitive exclusion by Bacillus subtilis spores of Salmonella enterica serotype Enteritidis and Clostridium perfringens in young chickens. Veterinary Microbiology 2003;94:245256.

Li X, Xia C, Li Y. Induced expression of alpha-toxin gene of Clostridium perfringens in recombinant Lactobacillus casei and their immunoprotective in mice. Acta Microbiologica Sinica 2009;49:11151120

Mahdavi AH, Rahmani HR, Pourreza J. Effect of probiotic supplements on egg quality and laying hen's performance. International Journal of Poultry Science 2005;4:488-492. 
Manafi M. Comparison study of a natural non-antibiotic growth promoter and a commercial probiotic on growth performance, immune response and biochemical parameters of broiler chick. The Journal of Poultry Science 2015;52:274-281.

Nahashon SN, Nakaue HS, Mirosh LW. Effect of direct-fed microbials on nutrient retention and production parameters of laying pullets. Poultry Science 1992;71(Suppl 1):111.

Nahashon SN, Nakaue HS, Mirosh LW. Performance of single comb white leghorn layers fed a diet with live microbial during the growth and egg laying phases. Animal Feed Science and Technology 1996;57:25-38.

National Research Council. Nutrient requirements of poultry. 9th rev. ed. Washington: National Academy Press; 1994

Nisbet DJ, Tellez GI, Lowry VK, Anderson RC, Garcia G, Nava G, et al. Effect of a commercial competitive exclusion culture (preempt) on mortality and horizontal transmission of Salmonella gallinarum in broiler chickens. Avian Diseases 1998;42:651-656.

Onol AG, Sari M, Oguz FK, Gulcan B, Erbas G. Sürekli sýcak stresinde bulunan yumurtlama dönemindeki bildircinlarin rasyonlarina probiotik katkisinin bazi verim ve kan parametreleri üzerine etkisi. Türk Veterinerlik ve Hayvancilik Dergisi 2003;27:1397-1402.

Patterson JA, Burkholder KM. Application of prebiotics and probiotics in poultry production. Poultry Science 2003;82:627-631.

Pedroso AA, Moraes VMB, Ariki J. Performance and egg quality from 50 to 66 weeks old laying hens supplemented probiotic. Ciencia Rural 2001;31(4):683-686

Pellegrini S, Busso JM, Lèche A, Marin RH. Effects of diet, time since defecation, and drying process of the droppings on corticosterone metabolite measurements in Japanese quail Poultry Science 2015;94:1068-1074.

Romanin D, Serradell M, Gonzalez Maciel D, Lausada N, Garrote GL, Rumbo M. Down-regulation of intestinal epithelial innate response by probiotic yeasts isolated from kefir. International Journal of Food Microbiology 2010;140:102-108

SAS Institute. SAS/STAT user's guide. Version 9. 2nd ed. Cary; 2007.

Tavaniello S, Maiorano G, Siwek M, Knaga S, Witkowski AD, Memmo D, et al. Growth performance, meat quality traits, and genetic mapping of quantitative trait loci in 3 generations of Japanese quail populations (Coturnix japonica). Poultry Science 2014;93:2129-2140.

Tellez G, Higgins SE, Donoghue AM, Hargis B. Digestive physiology and the role of microorganisms. Journal of Applied Poultry Research 2006;15:136-144.

Tortuero F, Fernandez E. Effect of inclusion of microbial culture in barleybased diets fed to laying hens. Animal Feed Science and Technology 1995; $53: 255-265$

Vicente J, Torres-Rodriguez A, Higgins S, Pixley C, Tellez G, Donoghue AM, et al. Effect of a selected Lactobacillus spp-based probiotic on Salmonella enteritidis-infected broiler chicks. Avian Diseases 2008;52:143-146.

Vilà B, Fontgibell A, Badiola I, Esteve-Garcia E, Jimenez G, Castillo M, et al. Reduction of Salmonella enterica var. Enteritidis colonization and invasion by Bacillus cereus var. toyoi inclusion in poultry feeds. Poultry Science 2009;88:975-979.

Wagner RD, Paine DD, Cerniglia CE. Phenotypic and genotypic characterization of competitive exclusion products for use in poultry. Journal of Applied Microbiology 2003;94:1098-1107.

Weiss G, Rasmussen S, Zeuthen LH, Nielsen BN, Jarmer $H$, Jespersen L, et al. Lactobacillus acidophilus induces virus immune defence genes in murine dendritic cells by a toll-like receptor-2-dependent mechanism. Immunology 2010;131:268-281.

Yoruk MA, Gul M, Hayirli A, Macit M. The effects of supplementation of humate and probiotic on egg production and quality parameters during the late laying period in hens. Poultry Science 2004;83:84-88. 